\title{
Delivery Strategies for Stem Cell-Based Therapy
}

\author{
Jason P. Glotzbach MD, Victor W. Wong MD, Benjamin Levi MD, Michael T. \\ Longaker MD MBA, Geoffrey C. Gurtner* MD \\ Stanford University School of Medicine, Department of Surgery, Division of Plastic \\ and Reconstructive Surgery
}

Submitted March 2011. Accepted for publication August 2011

\begin{abstract}
Before stem cell-based therapies can become a clinical reality, technologies for cell delivery must be developed that can control differentiation and pluripotency, maintain a hospitable environment for cell survival and function, and provide a structural framework for regenerative healing of the target tissue. Insights gained from developmental and stem cell biology should guide the design of devices and techniques to facilitate stem cell-based therapies. Several strategies have been developed for surgical delivery of stem cells, including synthetic and biologic matrices for cell seeding, complex biochemical delivery devices for maintenance and modulation of stem cell properties, and smart constructs with the ability to adapt to the dynamic in vivo environment after implantation. In aggregate, surgical delivery of complex stem cell-seeded constructs has the potential to revolutionize surgical therapies for a wide range of diseases in order to provide a more regenerative platform for tissue and organ healing.
\end{abstract}

Keywords: regenerative medicine, stem cells, tissue engineering, surgical engineering, biomaterials, reconstructive surgery

\section{INTRODUCTION}

Over the past decade, regenerative medicine has evolved from a field focusing on the basic science of stem cells and developmental biology into one that actively seeks to solve clinical problems. The goal of regenerative medicine is to restore normal anatomic structure and physiologic function following injury or disease. Surgery represents a natural arena for the application of regenerative principles, both because of the acute nature of surgical disease (trauma, cancer resection, etc.) and the fact that surgeons have the freedom to intervene with a variety of different approaches. We believe that the utilization of stem cell-based therapies has the potential to revolutionize modern surgical care.

${ }^{*}$ Corresponding author: Professor and Associate Chair for Research, Department of Surgery, Stanford University School of Medicine, Professor (by courtesy) of Materials Science and Engineering, 257 Campus Drive, GK-201, Stanford, CA 94305-5148, Phone: 650.724.6672, Fax: 650.736.1142, email: ggurtner@stanford.edu. 
In order to apply stem cell-based therapies to treat surgical diseases, the materials and techniques that are employed must be to be both robust and relatively simple. To accomplish this goal, it will be necessary to develop physical constructs for delivery of cells to promote cell viability and engraftment in diverse and challenging environments, including soft tissue wounds and damaged organs. Lessons learned from the development and evolution of tissue engineering are useful to help conceptualize what these tools might look like.

Tissue engineering, as originally defined by Langer and Vacanti, aimed to develop "biological substitutes that restore, maintain, or improve tissue function" [1]. Practically, this meant the design of two-dimensional or relatively planar threedimensional support structures to create a niche for cell proliferation, differentiation and engraftment that could be implanted in the setting of an injured or missing tissue or organ [1]. As basic research into the molecular and cellular mechanisms of stem cell biology has matured, engineered delivery platforms have become more sophisticated to include precise release of growth factors and other modulatory chemicals and proteins to direct the behavior of seeded stem cells, for example, to direct differentiation into a specific cell type [2].

The ideal surgical strategy would involve a pre-designed and pre-fabricated system that could be pulled "off the shelf" and employed efficiently in the operating room at the time of the initial procedure to repair a damaged organ (as in trauma) or at the time of reconstruction (such as following cancer resection) [3]. The use of autologous cells would be strongly preferred to avoid the requirement for anti-rejection therapies to maintain the cells in the recipient [4]. Finally, it would be best to immediately utilize stem cells that had been concurrently harvested from the patient instead of waiting for a period of in vitro expansion because of the regulatory and commercial complexity of processes that require distant processing of cells. These requirements provide the justification for focusing on in vivo tissue engineering strategies, wherein cells are implanted on a scaffold or matrix to direct differentiation or paracrine function towards regeneration of the organ at the point of care. The objectives of this review are (a) to briefly summarize the clinical potential of various stem cell types, (b) to delineate the challenges that must be overcome for the successful development and implementation of stem cell-based therapy, (c) to discuss several different tissue engineering strategies to enable stem cell-based therapies, and (d) to discuss the role of surgical approaches to stem cell-based therapies.

\section{OVERVIEW OF STEM CELL BIOLOGY AND CHALLENGES TO STEM CELL-BASED THERAPIES}

A brief discussion of stem cell types and relevant biology is warranted to frame the discussion of surgical devices for stem cell delivery. Stem cells are classified based on their tissue of origin and their potency, which refers to the ability of a given cell population to differentiate into different cell types (Figure 1) [5]. Pluripotent stem cells such as embryonic stem cells (ESCs) and induced pluripotent stem cells (iPSCs) have the ability to form all cell types and represent the pinnacle of stem cell capacity. These cells do not exist in adults. ESCs are transiently present within the developing blastocyst, but rapidly differentiate into lineage-committed cells during development of 
the embryo and therefore cannot be isolated after the blastocyst stage [6]. iPSCs are generated by reprogramming somatic (differentiated) cells such as fibroblasts to revert to a pluripotent state $[7,8]$, a process that must be carried out in vitro.

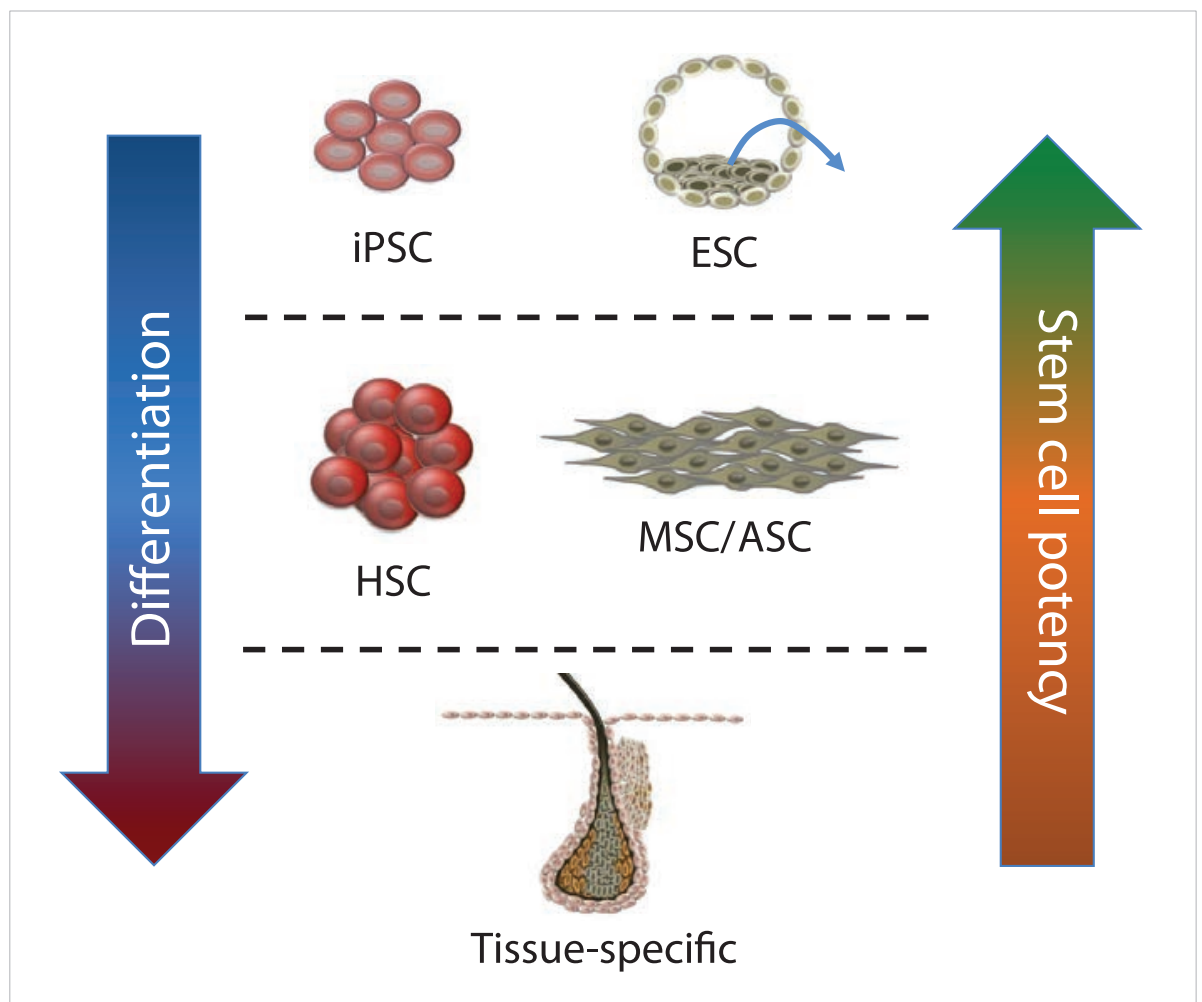

Figure 1. Overview of stem cell classification schemes. Different stem cell populations are characterized based on their potency, which is defined by their ability to form multiple different cell types (differentiation). Stem cells are also classified based on their tissue of origin.

Pluripotency confers profound stem cell capacity on the cells, but also leads to an instability and unpredictability. These cells form teratomas when implanted in vivo, and have a high rate of tumorogenesis [9]. In order to use pluripotent stem cells for cellbased therapy, one would need to prevent unregulated differentiation as well as mitigate the oncogenic potential of these cells. In addition, recent experimental work has demonstrated that iPSCs are significantly unstable once reprogrammed, which may be related to the complex epigenetic changes that occur during the reprogramming process, specifically chromatin remodeling and methylation [9]. Due to this instability and potential tumorgenesis, the timing and dosing of stem cell-based therapies will need to be precisely studied and controlled to minimize the risks of unintended effects of administering pluripotent cells clinically [10]. While certainly not insurmountable, 
these potential drawbacks have tempered the enthusiasm for moving ESC- and iPSCbased therapies into the clinic in the short term [11, 12].

Multipotent stem cells appear to be a more attractive candidate for initial clinical work. These include bone-marrow-derived mesenchymal stem cells (MSCs) and adipose-derived stromal cells (ASCs), which can form bone, cartilage, muscle, adipose tissue, and neurologic tissue in some investigators' hands [13, 14]. Hematopoietic stem cells (HSCs) are also multipotent, as they have the ability to form all blood cells [15]. Circulating progenitor cells, including endothelial progenitor cells (EPCs) and fibrocytes, have been shown to contribute to the maintenance of skin and the growth of blood vessels in normal (non-injured) states, as well as participating in cardiovascular repair in response to injury and hypoxia [16 - 18]. These groups of progenitor cells are also known as adult stem cells because they are typically isolated from adult tissues. Adult stem cells represent a promising class of cells for stem cell-based therapy because of their relative ease of isolation coupled with their ability to form multiple different tissue types and a potentially advantageous safety profile [19].

Finally, tissue-specific stem cells have been isolated from many different tissues, ranging from skin and intestine to the central nervous system and heart muscle. While tissues with high turnover such as skin and intestine have very active stem cell populations [20], less regenerative tissues such as heart and nervous tissue have much less active resident stem cell populations [21,22]. Tissue-specific stem cells are less appealing as therapeutic options largely due to the difficulty in harvesting these cells in sufficient numbers. For example, the morbidity associated with collection of central nervous system resident stem cells from the subventricular zone of the brain precludes routine harvest and isolation of these cells for cell-based therapy [23]. One strategy that may prove effective is augmenting the intrinsic regenerative potential of adult organs by activating resident tissue-specific stem cells in patients with an injury or disease process that is limited to a single organ $[20,24,25]$. While several groups are working to understand tissue-specific stem cell populations so they may be exploited therapeutically, this review will focus on multipotent and pluripotent cells.

\section{TISSUE ENGINEERING STRATEGIES FOR STEM CELL-BASED THERAPIES}

\subsection{Stem Cell Sorting and Differentiation}

Stem cell isolation protocols and procedures are specific to the tissue type of origin. MSCs and HSCs reside in the bone marrow, so bone marrow harvest and cell dissociation are necessary to isolate these cells. ASCs are harvested from subcutaneous adipose tissue using suction followed by collagenase digestion [13]. Stem cell sorting techniques have traditionally focused on surface protein expression profiles and fluorescence-activated cell sorting (FACS) technology to separate different cells from a heterogeneous population of stem/progenitor cells. This paradigm was initially described for HSCs [26], but has now been applied to multiple stem cell types and remains the most commonly used method for the selection of specific stem cell subpopulations. Many groups are working to refine the selection parameters for adult stem cells, including MSCs and ASCs [27, 28]. These adult stem cell populations are known to be heterogeneous, and there is increasing evidence that sorting for subpopulations may allow enrichment for stem cell populations with predilections to form specific tissue types [29-31]. 


\subsection{Native Scaffolds for Stem Cell Delivery}

The use of structural matrices for stem cell delivery offers several important benefits (Figure 2) [32]. Firstly, it allows for targeted delivery of the cell population directly into the intended area with minimal off-target effects. In addition, seeding cells on a scaffold can introduce larger numbers of cells without subjecting the cells to the trauma of direct injection. Moreover, a scaffold can provide a biomimetic extracellular environment with appropriate biochemical and structural cues to optimize stem cell function. Finally, scaffolds can themselves permanently integrate into the host site or can be designed to gradually degrade as host tissues repopulate the defect site. Ideally, the scaffolds themselves would modulate the surrounding environment and work synergistically with the delivered stem cells to effect tissue regeneration.

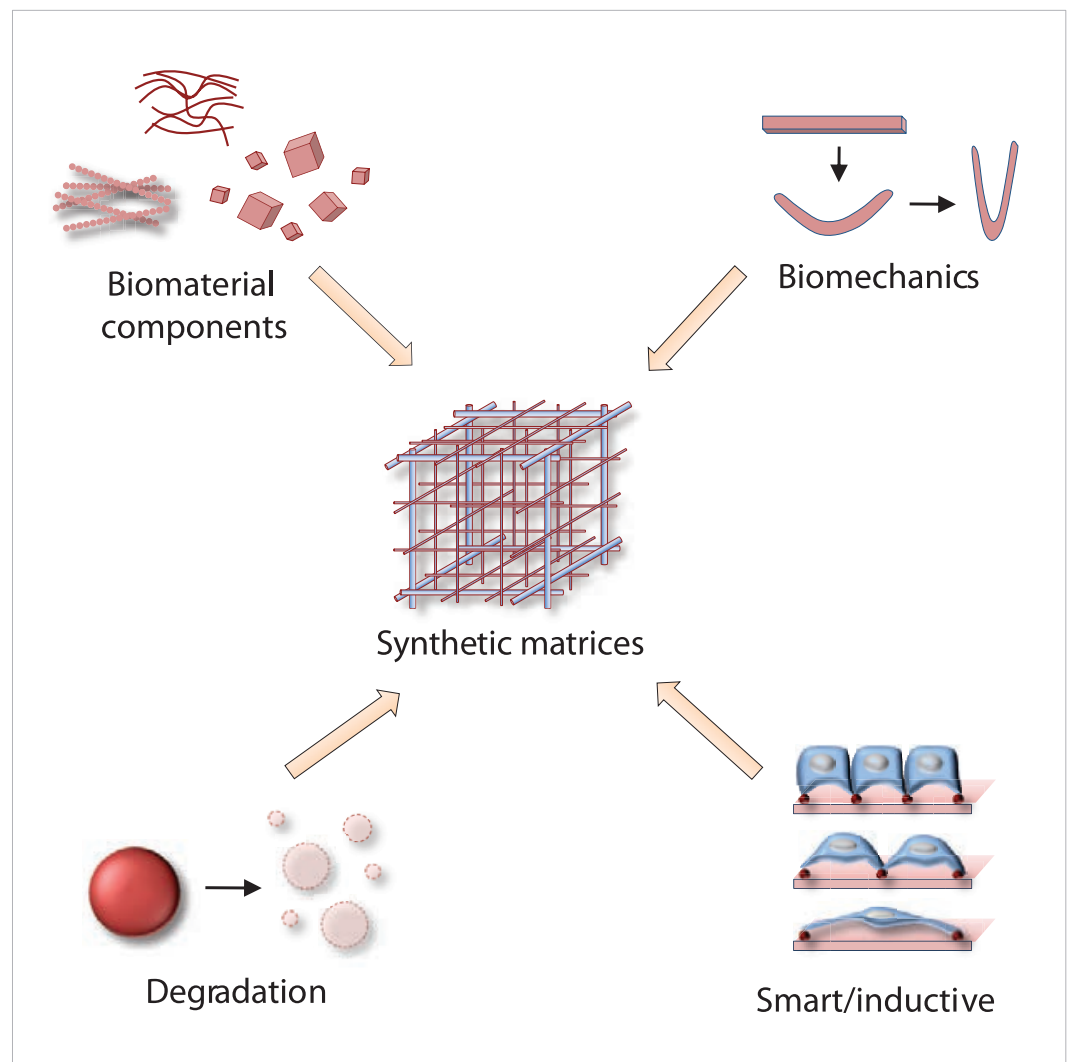

Figure 2. Synthetic matrices for tissue engineering paradigms. Biocompatible matrices and scaffolds can be synthesized from biomaterial constructs to provide the structural framework to enable stem-cell-based therapies. Synthetic scaffolds have the flexibility to incorporate bioactive molecules and proteins such as growth factors that can be used to modulate the behavior of seeded cells in vivo. By designing matrices with specific biomechanical and chemical properties, stem cell-based therapies can be precisely targeted to a specific clinical need. 
Native scaffolds are derived directly from extracellular matrix systems of various tissues and organs and are often decellularized to remove antigenic cellular contents [33 - 35]. They can range in complexity from microencapsulation of individual cells up to large decellularized organ constructs [36]. After decellularization, the resulting matrix can be utilized as a scaffold on which to seed cell populations. Importantly, these organized extracellular matrices already contain the architectural and material cues that are ideal for a tissue-specific function. The removal of cells eliminates immunogenicity and allows for a greater range of applications as cell-free allogeneic/xenogeneic constructs can be processed and stored for extended periods ex vivo [37].

The most extensive clinical experience in the use of cell-free native scaffolds is in skin engineering following burn injury [38 - 40]. Allogeneic decellularized human dermis is a standard tool used by reconstructive surgeons to treat burns, and its use has expanded to use for reconstruction procedures throughout the body [41, 42]. Decellularized aortic allografts have been successfully used for tracheal reconstruction in preclinical studies [43]. Porcine small intestine submucosa has been widely applied to animal models of skin, nerve, bone, urologic, and vascular injury [44] and has been used clinically to reconstruct tissues, such as for urologic and foot reconstruction [45, 46].

The opposite end of the spectrum is the use of cell-matrix constructs consisting of terminally differentiated cells, such as fibroblasts and matrix components. These have found clinical application in chronic wounds to augment healing [47 - 50]. These constructs have demonstrated the feasibility of seeding cells in conjunction with growth factors and supportive proteins onto a structural matrix or scaffold to provide a threedimensional environment conducive to cell survival. Several of these products are currently available commercially (Apligraf®, Organogenesis, Inc., Canton, MA and Dermagraft ${ }^{\circledR}$, Advanced Biohealing, Inc., Westport, CT). These approaches are gaining popularity to treat chronic cutaneous wounds, and suggest that a similar approach using stem cell-based constructs for other applications would be technically feasible.

Similarly, stem cells can be seeded onto natural acellular matrices for tissue engineering. Initially, simpler tissue/organ constructs have been attempted, including stem cell-seeded skin, muscle, nerve, bladder, and blood vessel [51 - 55]. Why stem cells appear to improve function in these preclinical studies remains unclear and is the focus of intense investigation. Although it is known that stem cells themselves can differentiate and self-renew, they also have a regenerative effect through paracrine-type interactions [56]. The interactions between stem cells and their delivery matrix are different in vitro when compared to placing the construct in vivo in the defect environment. An understanding of these intricate interactions will be important as researchers attempt to fabricate increasingly complicated organs.

Another extremely promising approach is the method of decellularizing whole solid organs followed by seeding with progenitor-type cells. Rat hearts can be decellularized through established techniques, repopulated with neonatal cardiac or aortic endothelial cells, matured in a bioreactor system, and then re-implanted, where they have been shown to have functional contractile and electrical activity [57]. This approach (decellularization and seeding) has been used to construct an artificial lung that was orthotopically transplanted in a rat model [58]. Similar methods have been used to decellularize liver grafts, repopulate them in vitro with adult hepatocytes, and transplant them back into rats 
with evidence of improved liver function [59]. These techniques demonstrate the feasibility of decellularizing organs to isolate intact matrix and subsequently seeding progenitor-type cells into these scaffolds in the appropriate biophysical environment to generate large-scale functional organs that can be transplanted.

Despite the preclinical promise of native scaffolds in stem cell-based regenerative therapies, there are some important drawbacks in their translation to clinical medicine. Native scaffolds are generally scarce and expensive, much like organs for transplantation. Surgical harvest of matrix scaffolds from living patients is a major procedure and harvest of allogeneic/xenogeneic materials carry the risk of disease transmission as well as important ethical concerns. The benefit of adding seeded stem cells remains unclear, and rigorous studies are needed to track stem cell fate and function following transplantation via these methods.

\subsection{Living Scaffolds}

Tissue engineering has traditionally attempted to fabricate complex organ-level structures by combining the most elementary components (cells, matrix, and biochemical factors) and coaxing regenerative processes in vitro. Although these hybrid constructs have proven effective for smaller defects or simpler tissues, the need for highly complex tissues and organs continues to grow as human populations expand and age. One of the major limitations of tissue engineering attempts is the volume of tissue that can be generated. Larger tissue constructs are highly dependent on the vascular supply as the diffusion capacity of nutrients and metabolic wastes is generally limited to the cellular level [60]. In living tissues, the mass transport of nutrients and waste is achieved through a functional macro- and microcirculatory system and attempts to fully recapitulate this complex system in engineered cell/matrix/biochemical constructs have proven to be exceedingly challenging. Further, even if a rudimentary microvessel system is developed, the ability to integrate these "vascularized" structures with the host circulatory system remains difficult.

An example of a "living scaffold" is a tissue flap, which is an independent microcirculatory network transferred from its original location to an area where tissue is missing most frequently from a traumatic or postsurgical cause. Microvascular free flaps can transfer numerous tissues with their native blood supply such as skin, subcutaneous tissue, muscle, and bone as a means to address traumatic or surgical defects. Reconstructive surgeons employ autologous tissues for myriad reconstructive procedures to replace damaged or defect tissues throughout the body. These flaps are an important tool in the armamentarium of reconstructive surgeons as they are functional, autologous, and largely expendable constructs that can be transferred throughout the body and re-integrated with the circulation via standard microsurgical techniques [4].

Recently, microvascular free flaps have been proposed as a delivery vehicle for stem cells (Figure 3) [61 - 63]. Our group has developed a bioreactor-based system utilizing autologous free flaps in rats using the superficial inferior epigastric (SIE) groin flap based on the SIE artery and vein [64 - 67]. We have demonstrated the ability to perfuse harvested rat SIE flaps ex vivo for up to 24 hours on a bioreactor system while controlling perfusion rate, oxygenation, and $\mathrm{pH}$. These free flaps can be transfected ex vivo with adenoviral-based methods to produce therapeutic peptides (such as anti- 
microbial proteins and immunotherapeutic cytokines) following microsurgical reimplantation for clinical effect [64 - 66]. We have also shown that stem cells can be seeded onto these scaffolds via bioreactor perfusion and that delivered stem cells successfully egress and engraft in clusters around the vasculature [67]. Most importantly, these engineered constructs are easily transplanted back into recipient rats and re-integrated into the circulatory system.

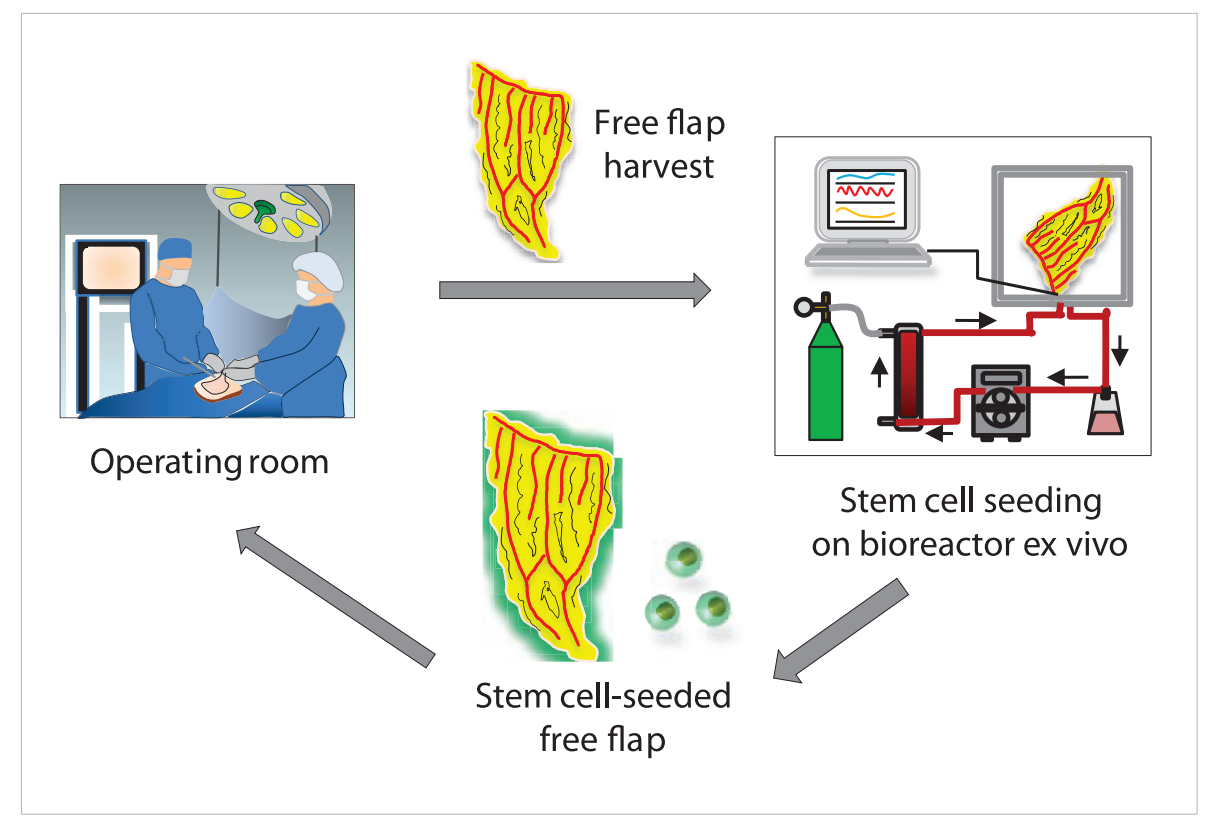

Figure 3. Living tissue as the basis for tissue engineered constructs. Free flaps are harvested from nonessential soft tissues such as the abdominal wall and include a vascular bed that can be used to seed stem cells on the flap. Ex vivo bioreactor systems can be used to maintain the viability of the flap tissue as well as the seeded cells, which then allows for re-implantation into the patient as vascularized tissue graft.

A somewhat similar approach is the prefabrication of microvascularized constructs for tissue engineering, which has been pioneered by Morrison et al. from the O'Brien Institute of Microsurgery in Australia. This group has focused on generating a vascular supply for engineered tissue through pre-fabrication techniques in the patient themselves. The resulting tissue has the capacity to grow with the host and become a permanent vascularized tissue [68]. To this end, they have employed native vascular conduits as the basis of several vascularized three-dimensional constructs [3, 69]. They also recently reported in vivo expansion of hepatocyte and pancreatic islet cell progenitors using three-dimensional vascularized constructs $[70,71]$ and generation of adipose tissue, raising the possibility of a clinical trial using tissue engineered constructs for breast reconstruction [72]. 
For both of these approaches, in terms of clinical translation, expendable human tissues such as the intra-abdominal omentum might be ideal. The omentum could be harvested laparoscopically and connected to a scaled up bioreactor system that would allow the same manipulations as we have shown to be feasible in small animal models. Autologous cells could also be readily harvested from patients via skin biopsy or lipoaspiration, expanded ex vivo, manipulated with molecular and genetic tools, and seeded onto these vascularized scaffolds. This technology could potentially change the way organs are engineered by providing a vascularized pre-formed matrix on which to seed stem cells for surgical applications (Figure 4).

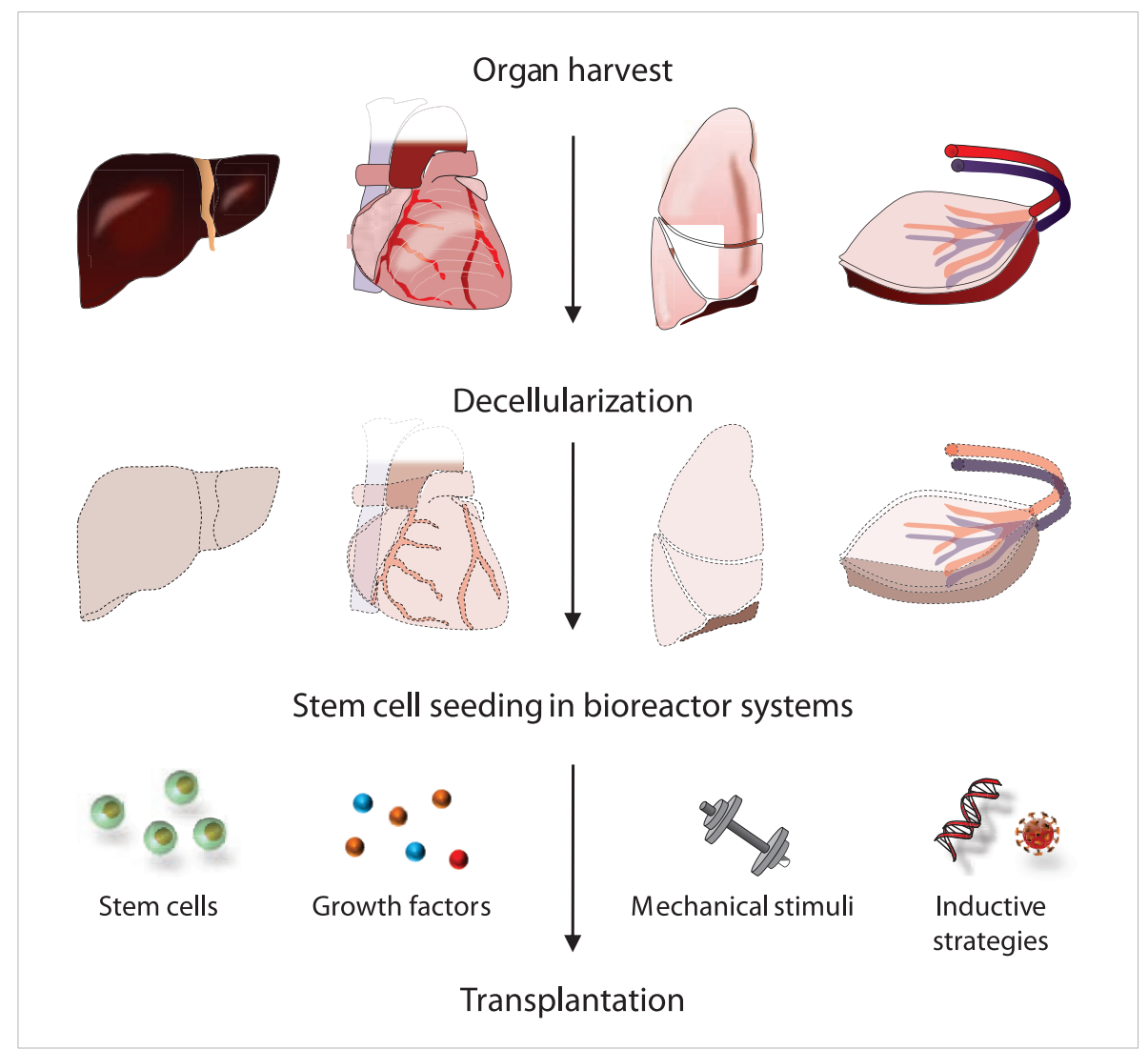

Figure 4. Organ level tissue engineering using stem cells seeded on native vascular beds. In order to regenerate complex solid organs, tissue engineered constructs must include a vascular supply. One strategy to accomplish this is to harvest native tissues and organs (which include their native vascular and capillary networks), decellularize the tissue, and then seed the graft with stem cells in addition to growth factors and other modulatory elements to promote regeneration of a specific organ after transplantation. 


\subsection{Recreating the Stem Cell Niche with Synthetic Scaffolds}

In vivo, stem cells reside in specific anatomic and physiologic niches that precisely regulate stem cell function and maintain an undifferentiated state. The prototypical stem cell niche is occupied by the HSC in the bone marrow endosteal sinusoids, where osteoclasts, osteoblasts, and endothelial cells work in a synchronized fashion to maintain HSCs in a quiescent yet responsive state [73-75]. The niche is much more than an anatomic location, as the stromal and supportive cells maintain the resident stem cell populations in a state of de-differentiation, allowing them to maintain homeostasis of a specific tissue type [76]. In order to maximize the therapeutic potential of stem cells, surgical strategies that can recapitulate the stem cell niche, or at least specific components of the niche, are most likely to be successful.

Synthetic scaffolds can be fabricated from biologic and/or non-biologic substrates [77]. Biologic materials are derived from living systems and subsequently reconstituted into an organized template. Examples include matrices constructed from collagens, carbohydrates, glycosaminoglycans, silk, etc., all of which have been used for numerous tissue engineering applications [78 - 80]. Inert materials have also been used for engineering scaffolds and include titanium, ceramics, and steel largely for orthopedic and dental applications [81]. Synthetic biodegradable polymers that have been used as porous templates for many years include the polymers polylactic acid (PLA), polyglycolic acid (PGA), polycaprolactone (PCL) and polyethylene glycol (PEG) [82].

In addition to providing structural support and a hospitable environment, surgical delivery devices have the potential to modulate stem cell proliferation, differentiation and eventual engraftment into a target tissue through the controlled release of growth factors and other signaling molecules (Figure 5) [2]. In ESCs and iPSCs, pluripotency can be maintained in vitro by supplementation with leukemia inhibitory factor, fibroblast growth factor 2, bone morphogenetic proteins, and many other factors [9, 83 - 85]. WNT/ $\beta$-catenin signaling, TGF- $\beta$ signaling, insulin-like growth factor, and ERK signaling augment proliferation and self-renewal of ESCs in vitro. However, these factors would not be useful in vivo where differentiation, and not pluripotency, is the goal $[9,85]$. Nevertheless, the lessons learned from in vitro culture systems for maintenance of ESCs and iPSCs may help design strategies to optimize stem cell survival during the time of initial seeding onto biologic and biomimetic constructs. Recreation of an appropriate niche may be even more important in the therapeutic delivery of MSCs, HSCs, and ASCs because these cells are largely dependent on external cues to maintain self-renewal and proliferation [86]. For example, Adams et al. reported modulation of the HSC niche using parathyroid hormone administration for osteoblast augmentation [87].

Biomaterial fabrication techniques are increasingly sophisticated and allow for nanoscale control of scaffold dimensions and properties [88]. Scaffold engineers can modulate biochemical and mechanical properties, pore size, degradability, etc., to optimize the environment for stem cell function [89]. Specific ligands and matrix elements can also be precisely patterned to recapitulate the temporospatial cues of a regenerative niche. Nanofabrication techniques allow for increasingly precise regulation of scaffold topography and include techniques such as electrospinning, selfassembly, and nano-level lithographic technologies [90]. 


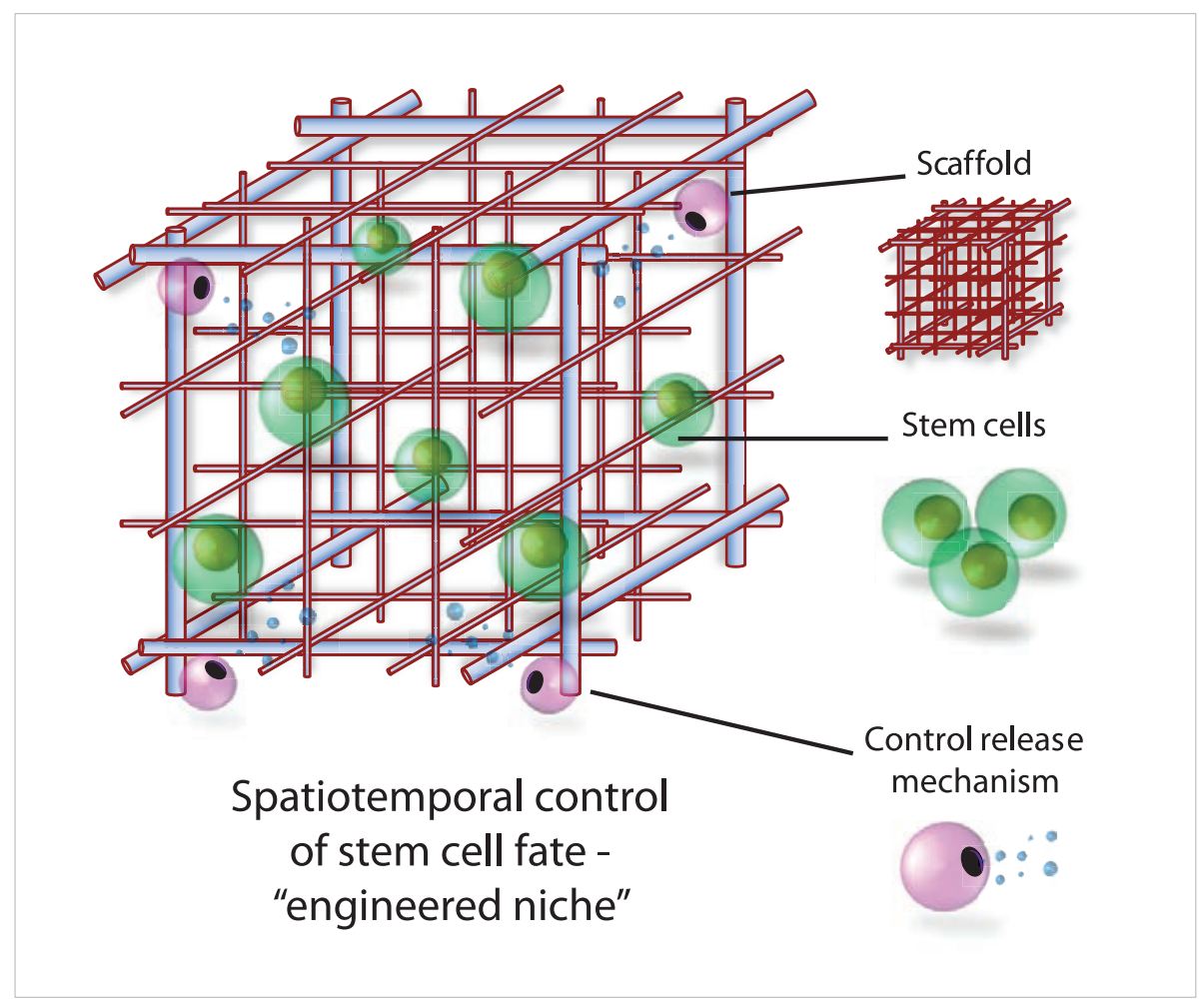

Figure 5. Engineering the stem cell niche. Stem cells are maintained in vivo in precise anatomical and physiologic niches that prevent differentiation and support stem cell proliferation to maintain a pool of stem cells to support tissue homeostasis. By precisely recreating this niche in vivo using tissue engineered constructs, seeded stem cells can be directed to differentiate into specific tissues or to support tissue regeneration through paracrine functions. As understanding of stem cell biology improves, the tools available to tissue engineering approaches will become more sophisticated.

A new class of biomaterials capable of inducing specific behaviors has been increasingly utilized in tissue engineering and regenerative medicine [91]. These "smart" materials actively interact with surrounding cells and functionally participate in numerous repair processes [92]. Reciprocal crosstalk between stem cells and their delivery scaffold occurs through direct cell-matrix attachments, three-dimensional structural cues, mechanical force transduction, and control of morphogenic gradients between recipient tissues and seeded stem cells. These complex interactions importantly regulate stem cell function, differentiation, and survival during repair processes [93]. As the fields of stem cell biology and biomaterial engineering continue to converge, future stem cell delivery systems will increasingly utilize the scaffold microenvironment to guide tissue and organ morphogenesis. 
Stem cell populations have been seeded onto synthetic scaffolds to reconstruct almost all tissues and have been largely successful in preclinical models [94 - 96]. A comprehensive discussion of each tissue type is beyond the scope of this article, but overall, the importance of stem cells in the future of regenerative medicine is certain. In general, various synthetic scaffolds that match the biochemical and biophysical properties (e.g., size, porosity, stiffness, degradation rate) of the tissue to be replaced are seeded with the tissue-specific progenitor cell. The hybrid construct is usually matured in vitro to allow engraftment and/or differentiation of the stem cells, but cells can also be seeded at the time of surgery when the synthetic scaffold is placed.

The general benefits of synthetic scaffolds compared to natural scaffolds are their wider availability, lower cost, and ability to be produced in large quantities, along with the knowledge base to control and modify their fabrication to suit a diverse range of tasks [77]. As the molecular details of stem cell niches are increasingly understood and the ability of biomaterial engineers to mimic these environments improves, synthetic scaffolds will continue to have an important role in regenerative medicine.

\subsection{In Vivo Reprogramming and Differentiation}

With the increasing sophistication of reprogramming strategies to achieve pluripotency from somatic cells coupled with the development of differentiation protocols to reliably produce specific lineage cell types form stem cells, the prospects for in vivo directed reprogramming and differentiation is becoming more feasible. Autologous pluripotent cells could be obtained from reprogramming of somatic cells from patient's own somatic cells, but pluripotency may not even be a requisite step to achieve stem cell differentiation into a specific cell type. Vierbuchen et al. recently reported the direct conversion of fibroblasts to neurons [97], and Ieda et al. demonstrated that resident cardiac fibroblasts can be converted to cardiomyocytes by defined factors [98]. Other groups have reported direct reprogramming of exocrine pancreatic cells to islet cells [99]. To obviate the need for pluripotent cells would simplify future applications of stem cell-based therapies.

Adult multipotent stem cells would have the highest utility in cell-based therapy if they could be directed toward a specific fate in vivo, without requiring an in vitro expansion period before implantation. ASCs form bone when placed in a highly osteogenic environment of a critically sized calvarial defect in the presence of a hydroxyapatite-coated PLGA scaffold [100]. Polyethylene glycol (PEG) hydrogel encapsulation of MSCs functionalized with either phosphate or t-butyl methacrylate small functional groups have also been shown to promote osteogenic and adipogenic differentiation [101]. Hydrogels with differentiation-promoting signaling molecules have been described for soft tissue engineering. Adipogenesis and myogenesis may be feasible using this approach. Both MSCs and ASCs have been shown to form skeletal muscle, but myocardium has been more challenging [102].

The success of a reconstructive or regenerative approach to surgical disease would be greatly enhanced if all interventions could be accomplished within the setting of a single clinical intervention. Direct reprogramming and differentiation strategies would allow such a "single operation" approach to become feasible, as autologous cells could be isolated concurrently with the primary surgical intervention, and seeded onto a 
matrix or scaffold that releases appropriate signals for proliferation. As any cell-based approach would require a large number of cells to reach clinical relevance, it is likely that adult multipotent stem cells such as ASCs, which have been shown to reprogram more efficiently than somatic cells [103], will provide adequate numbers for development of such single procedure strategies.

\section{SURGICAL PROCEDURES FOR STEM CELL DELIVERY}

In order to combine stem cell-based therapies with current surgical techniques as a regenerative tool to replace missing or dysfunctional tissues, procedures will need to be modified and developed to reflect this need. Broadly speaking, there are three strategies for administering stem cells therapeutically, including systemic intravascular injection, guided local injection directly into the affected tissue, or surgical implantation of a stem cell-seeded construct that could vary in complexity from a simple two-dimensional "patch" up to a completely engineered organ (Figure 6). The recent boom in stem cell biology, biomaterials, and tissue engineering research has led to increased understanding of the conditions that are necessary for successful introduction of both stem cells and differentiated cells into the body through an injection or transplantation.

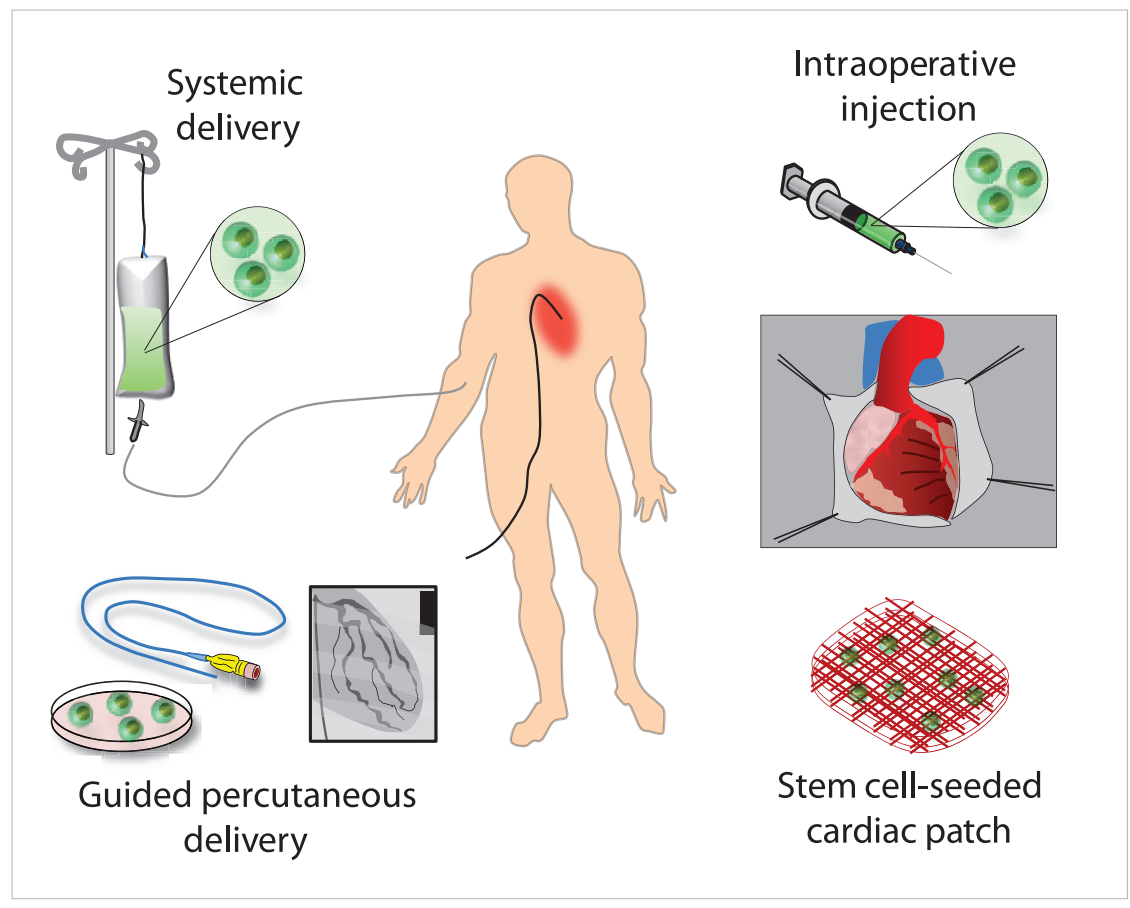

Figure 6. Potential methods for clinical delivery of stem cells for cell-based therapies. Clinical options for delivery of stem cells for cell-based therapy range from simple injection to complex scaffold seeding paradigms. Surgical exposure of target organs and tissue will facilitate direct injection of cells to address a specific defect, and stem cell-seeded scaffolds will likely require surgical transplant to be effective for tissue or organ regeneration. 
Perhaps one of the most translatable areas of research lies in bone tissue replacement. Recent case studies have focused on the use of human ASCs (hASCs) to treat osseous defects [104]. In limited case reports, defects of the maxilla [105], mandible [106], and calvaria [107] have demonstrated more robust healing with the use of hASCs. Such reconstructions eliminate the need for alloplastic materials, and thus reduce the risk of infection, breakdown, or rejection. Lendeckel et al. isolated hASCs and seeded them on nonvascularized bone grafts using fibrin glue. These bone grafts with fibrin and hASCs were then used to treat a 7-year-old patient with widespread calvarial defects after calvarial trauma [107]. Mesimaki et al. were able to deliver hASCs on a vascularized titanium scaffold implanted in the rectus abdominus muscle. The muscle and titanium implant were harvested as a microvascular flap and seeded with hASCs, beta-tricalcium phosphate, and BMP-2 to heal a large defect in the maxilla, reporting a promising outcome up to 8 months post-operatively in this single human patient case study [105]. Another group demonstrated improved bony healing in mandibular and maxillary defects using implanted hASCs [106]. These findings are encouraging as they combine multipotent cells (hASCs) with the proven surgical procedures of bone grafting and free flap transfer to augment osseous healing. The goal of a tissue engineering approach would be to combine these techniques by constructing a scaffold in the specific shape of a tissue defect, seeding the scaffold with autologous osteocapable cells such as hASCs, and transferring the engineered construct along with a genetically primed microvascular tissue flap, therefore providing vascularized autogenous de novo bone.

Stem cell-mediated gene therapy has also been applied to liver disease, and transplantation of isolated hepatocytes has also been used to treat liver disorders. Studies have demonstrated that hepatocyte engraftment into a failing liver or extrahepatic sites can help correct liver-mediated metabolic deficiencies and prolong survival in animals with liver failure [108 - 113]. Regardless of the tissue transplanted, survival remains a significant challenge. Specific scaffolds can be designed to provide a substrate for cells to allow for adhesion, control localization, and regulate gene expression and differentiation. Furthermore, scaffolds should induce vascularization or, in the case of flaps, come with their own vascularization to optimize cell survival.

Several clinical trials have been performed using systemic or intracoronary injection of bone marrow-derived stem cells after myocardial infarction, but the results have been somewhat disappointing [114 - 118]. In response to these results, many groups have described surgically implantable stem cell-seeded patches to achieve myocardial repair [119 - 123]. As these strategies mature, surgical implantation of myocardial patch with stem cell seeding may prove to offer a regenerative approach to correcting cardiac muscle damage following myocardial infarction. In addition, Geron Inc, a biotechnology company, has begun enrolling patients in a Phase I clinical trial with the aim of treating subacute (7-14 days post-injury) thoracic spinal cord injury using human embryonic stem cells [124, 125]. Although concerns have been raised about study design [126, 127], this trial represents an important step in the development of delivery strategies for stem cell-based therapies. 


\section{CONCLUSIONS AND FUTURE DIRECTION}

As regenerative medicine and stem cell-based therapies mature into clinically viable options, surgical techniques to implant stem cells within two- and three-dimensional constructs will play an important role in bringing this new paradigm to the clinic. The two main hurdles preventing widespread clinical use of stem cell-based therapies include the prohibitive cost of prolonged in vitro expansion of stem and progenitor cell populations and imprecise differentiation patterns of implanted cells. Through precise engineering of surgical constructs that can support stem cell proliferation and promote tissue-specific differentiation, the goal of truly regenerative surgical therapies may be realized.

\section{CONFLICT OF INTEREST: None.}

\section{REFERENCES}

\section{References}

[1] Atala A. Engineering tissues, organs and cells. Journal of tissue engineering and regenerative medicine. 2007; 1(2): 83-96.

[2] Lutolf MP, Gilbert PM, Blau HM. Designing materials to direct stem-cell fate. Nature. 2009; 462(7272): 433-441.

[3] Zdolsek JM, Morrison WA, Dingle AM, Palmer JA, Penington AJ, Mitchell GM. An "off the shelf" vascular allograft supports angiogenic growth in three-dimensional tissue engineering. Journal of vascular surgery : official publication, the Society for Vascular Surgery [and] International Society for Cardiovascular Surgery, North American Chapter. 2011; 53(2): 435-444.

[4] Glotzbach JP, Wong VW, Gurtner GC, Longaker MT. Regenerative medicine. Current problems in surgery. 2011; 48(3): 148-212.

[5] Weissman IL. Stem cells: units of development, units of regeneration, and units in evolution. Cell. 2000; 100(1): 157-168.

[6] McCulloch EA, Till JE. Perspectives on the properties of stem cells. Nature Medicine. 2005; 11(10): 1026-1028.

[7] Takahashi K, Tanabe K, Ohnuki M, Narita M, Ichisaka T, Tomoda K, Yamanaka S. Induction of pluripotent stem cells from adult human fibroblasts by defined factors. Cell. 2007; 131(5): 861-872.

[8] Takahashi K, Yamanaka S. Induction of pluripotent stem cells from mouse embryonic and adult fibroblast cultures by defined factors. Cell. 2006; 126(4): 663-676.

[9] Jaenisch R, Young R. Stem cells, the molecular circuitry of pluripotency and nuclear reprogramming. Cell. 2008; 132(4): 567-582.

[10] Daley GQ, Lensch MW, Jaenisch R, Meissner A, Plath K, Yamanaka S. Broader implications of defining standards for the pluripotency of iPSCs. Cell Stem Cell. 2009; 4(3): 200-201; author reply 202.

[11] Amabile G, Meissner A. Induced pluripotent stem cells: current progress and potential for regenerative medicine. Trends Mol Med. 2009; 15(2): 59-68.

[12] Okita K, Ichisaka T, Yamanaka S. Generation of germline-competent induced pluripotent stem cells. Nature. 2007; 448(7151): 313-317.

[13] Zuk PA, Zhu M, Mizuno H, et al. Multilineage cells from human adipose tissue: implications for cellbased therapies. Tissue Eng. 2001; 7(2): 211-228.

[14] Pittenger MF, Mackay AM, Beck SC, et al. Multilineage potential of adult human mesenchymal stem cells. SCIENCE. 1999; 284(5411): 143-147.

[15] Orkin SH, Zon LI. Hematopoiesis: an evolving paradigm for stem cell biology. Cell. 2008; 132(4): 631-644.

[16] Asahara T, Murohara T, Sullivan A, et al. Isolation of putative progenitor endothelial cells for angiogenesis. SCIENCE. 1997; 275(5302): 964-967.

[17] Hill JM, Zalos G, Halcox JP, Schenke WH, Waclawiw MA, Quyyumi AA, Finkel T. Circulating endothelial progenitor cells, vascular function, and cardiovascular risk. N Engl J Med. 2003; 348(7): 593-600. 
[18] Herzog EL, Bucala R. Fibrocytes in health and disease. Experimental Hematology. 2010; 38(7): 548556.

[19] Prockop DJ. Repair of tissues by adult stem/progenitor cells (MSCs): controversies, myths, and changing paradigms. Molecular therapy : the journal of the American Society of Gene Therapy. 2009; 17(6): 939-946.

[20] Blanpain C, Horsley V, Fuchs E. Epithelial stem cells: turning over new leaves. Cell. 2007; 128(3): 445-458.

[21] Kokovay E, Shen Q, Temple S. The incredible elastic brain: how neural stem cells expand our minds. Neuron. 2008; 60(3): 420-429.

[22] Laugwitz KL, Moretti A, Lam J, et al. Postnatal isl1+ cardioblasts enter fully differentiated cardiomyocyte lineages. Nature. 2005; 433(7026): 647-653.

[23] Kuo CT, Mirzadeh Z, Soriano-Navarro M, et al. Postnatal deletion of Numb/Numblike reveals repair and remodeling capacity in the subventricular neurogenic niche. Cell. 2006; 127(6): 1253-1264.

[24] Chistiakov DA. Endogenous and exogenous stem cells: a role in lung repair and use in airway tissue engineering and transplantation. Journal of biomedical science. 2010; 17(92.

[25] Nakamura M, Tsuji O, Bregman BS, Toyama Y, Okano H. Mimicking the neurotrophic factor profile of embryonic spinal cord controls the differentiation potential of spinal progenitors into neuronal cells. PLOS ONE. 2011; 6(6): e20717.

[26] Spangrude GJ, Heimfeld S, Weissman IL. Purification and characterization of mouse hematopoietic stem cells. SCIENCE. 1988; 241(4861): 58-62.

[27] Mosna F, Sensebe L, Krampera M. Human bone marrow and adipose tissue mesenchymal stem cells: a user's guide. Stem Cells and Development. 2010; 19(10): 1449-1470.

[28] Kolf CM, Cho E, Tuan RS. Mesenchymal stromal cells. Biology of adult mesenchymal stem cells: regulation of niche, self-renewal and differentiation. Arthritis Res Ther. 2007; 9(1): 204.

[29] Glotzbach JP, Januszyk M, Vial IN, et al. An Information Theoretic, Microfluidic-Based Single Cell Analysis Permits Identification of Subpopulations among Putatively Homogeneous Stem Cells. PLoS ONE. Accepted for publication May 2011;

[30] Levi B, Glotzbach JP, Januszyk M, et al. Single Cell Analysis Identifies CD105 as a Marker for Enrichment of Human Adipose-Derived Stromal Cells to Enhance Skeletal Healing. Under review, Journal of Biological Chemistry, Submitted May 2011;

[31] Phinney DG. Biochemical Heterogeneity of Mesenchymal Stem Cell Populations: Clues to their Therapeutic Efficacy. Cell Cycle. 2007; 6(23): 2884-2889.

[32] Discher DE, Mooney DJ, Zandstra PW. Growth factors, matrices, and forces combine and control stem cells. SCIENCE. 2009; 324(5935): 1673-1677.

[33] Badylak SF. The extracellular matrix as a biologic scaffold material. Biomaterials. 2007; 28(25): 3587-3593.

[34] Badylak SF, Freytes DO, Gilbert TW. Extracellular matrix as a biological scaffold material: Structure and function. Acta Biomaterialia. 2009; 5(1): 1-13.

[35] Jhaveri-Desai H, Khetarpal S. Tissue Engineering in Regenerative Dental Therapy. Jour Healthcare Eng. 2011; 2(4): 405-426.

[36] Zhang W, He X. Microencapsulating and Banking Live Cells for Cell-Based Medicine. Jour Healthcare Eng. 2011; 2(4): 427-446.

[37] Badylak SF, Taylor D, Uygun K. Whole organ tissue engineering: decellularization and recellularization of three-dimensional matrix scaffolds. Ann Rev Biomed Eng. 2011; 13(

[38] Wainwright DJ. Use of an acellular allograft dermal matrix (AlloDerm) in the management of fullthickness burns. Burns. 1995; 21(4): 243-248.

[39] Askari M, Cohen MJ, Grossman PH, Kulber DA. The use of acellular dermal matrix in release of burn contracture scars in the hand. Plast Reconstr Surg. 2011; 127(4): 1593-1599.

[40] Yim H, Cho YS, Seo CH, et al. The use of AlloDerm on major burn patients: AlloDerm prevents post-burn joint contracture. Burns : journal of the International Society for Burn Injuries. 2010; 36(3): 322-328. 
[41] Bello YM, Falabella AF, Eaglstein WH. Tissue-engineered skin. Current status in wound healing. American journal of clinical dermatology. 2001; 2(5): 305-313.

[42] Butler CE, Langstein HN, Kronowitz SJ. Pelvic, abdominal, and chest wall reconstruction with AlloDerm in patients at increased risk for mesh-related complications. Plast Reconstr Surg. 2005; 116(5): 1263-1275; discussion 1276-1267.

[43] Seguin A, Radu D, Holder-Espinasse M, Bruneval P, Fialaire-Legendre A, Duterque-Coquillaud M, Carpentier A, Martinod E. Tracheal replacement with cryopreserved, decellularized, or glutaraldehyde-treated aortic allografts. Ann Thorac Surg. 2009; 87(3): 861-867.

[44] Hodde JP, Badylak SF, Brightman AO, Voytik-Harbin SL. Glycosaminoglycan content of small intestinal submucosa: a bioscaffold for tissue replacement. Tissue Eng. 1996; 2(3): 209-217.

[45] Knoll LD. Use of porcine small intestinal submucosal graft in the surgical management of Peyronie's disease. Urology. 2001; 57(4): 753-757.

[46] Bibbo C. The porcine small intestinal submucosa (SIS) patch in foot and ankle reconstruction. J Foot Ankle Surg. 2010; 49(2): 123-127.

[47] Barber C, Watt A, Pham C, Humphreys K, Penington A, Mutimer K, Edwards M, Maddern G. Influence of bioengineered skin substitutes on diabetic foot ulcer and venous leg ulcer outcomes. Journal of wound care. 2008; 17(12): 517-527.

[48] Ehrenreich M, Ruszczak Z. Update on tissue-engineered biological dressings. Tissue Engineering. 2006; 12(9): 2407-2424.

[49] Pham C, Greenwood J, Cleland H, Woodruff P, Maddern G. Bioengineered skin substitutes for the management of burns: a systematic review. Burns : journal of the International Society for Burn Injuries. 2007; 33(8): 946-957.

[50] Wong T, McGrath JA, Navsaria H. The role of fibroblasts in tissue engineering and regeneration. The British journal of dermatology. 2007; 156(6): 1149-1155.

[51] Conconi MT, De Coppi P, Bellini S, et al. Homologous muscle acellular matrix seeded with autologous myoblasts as a tissue-engineering approach to abdominal wall-defect repair. Biomaterials. 2005; 26(15): 2567-2574.

[52] Zhu WD, Xu YM, Feng C, Fu Q, Song LJ, Cui L. Bladder reconstruction with adipose-derived stem cell-seeded bladder acellular matrix grafts improve morphology composition. World J Urol. 2010; 28(4): 493-498.

[53] Nie C, Yang D, Morris SF. Local delivery of adipose-derived stem cells via acellular dermal matrix as a scaffold: a new promising strategy to accelerate wound healing. Med Hypotheses. 2009; 72(6): 679682.

[54] Walsh S, Biernaskie J, Kemp SW, Midha R. Supplementation of acellular nerve grafts with skin derived precursor cells promotes peripheral nerve regeneration. Neuroscience. 2009; 164(3): 10971107.

[55] Yang D, Guo T, Nie C, Morris SF. Tissue-engineered blood vessel graft produced by self-derived cells and allogenic acellular matrix: a functional performance and histologic study. Ann Plast Surg. 2009; 62(3): 297-303.

[56] Tang YL, Zhao Q, Qin X, Shen L, Cheng L, Ge J, Phillips MI. Paracrine action enhances the effects of autologous mesenchymal stem cell transplantation on vascular regeneration in rat model of myocardial infarction. Ann Thorac Surg. 2005; 80(1): 229-236; discussion 236-227.

[57] Ott HC, Matthiesen TS, Goh S-K, Black LD, Kren SM, Netoff TI, Taylor DA. Perfusion-decellularized matrix: using nature's platform to engineer a bioartificial heart. Nat Med. 2008; 14(2): 213-221.

[58] Ott HC, Clippinger B, Conrad C, Schuetz C, Pomerantseva I, Ikonomou L, Kotton D, Vacanti JP. Regeneration and orthotopic transplantation of a bioartificial lung. Nat Med. 2010; 16(8): 927-933.

[59] Uygun BE, Soto-Gutierrez A, Yagi H, et al. Organ reengineering through development of a transplantable recellularized liver graft using decellularized liver matrix. Nat Med. 2010; 16(7): 814-820.

[60] Rouwkema J, Rivron NC, van Blitterswijk CA. Vascularization in tissue engineering. Trends in Biotechnology. 2008; 26(8): 434-441. 
[61] Ismail A, Ramsis R, Sherif A, Thabet A, El-Ghor H, Selim A. Use of human amniotic stem cells for common bile duct reconstruction: vascularized support of a free amnion graft. Medical science monitor : international medical journal of experimental and clinical research. 2009; 15(9): BR243-247.

[62] Vats A, Birchall M. Stem cells and regenerative medicine: potentials and realities for rhinology. Rhinology. 2010; 48(3): 259-264.

[63] Kusuma S, Gerecht S. Engineering blood vessels using stem cells: innovative approaches to treat vascular disorders. Expert Rev Cardiovasc Ther. 2010; 8(10): 1433-1445.

[64] Ghali S, Bhatt KA, Dempsey MP, et al. Treating chronic wound infections with genetically modified free flaps. Plast Reconstr Surg. 2009; 123(4): 1157-1168.

[65] Dempsey MP, Hamou C, Michaels Jt, Ghali S, Jazayeri L, Grogan RH, Gurtner GC. Using genetically modified microvascular free flaps to deliver local cancer immunotherapy with minimal systemic toxicity. Plast Reconstr Surg. 2008; 121(5): 1541-1553.

[66] Michaels Jt, Levine JP, Hazen A, Ceradini DJ, Galiano RD, Soltanian H, Gurtner GC. Biologic brachytherapy: ex vivo transduction of microvascular beds for efficient, targeted gene therapy. Plast Reconstr Surg. 2006; 118(1): 54-65; discussion 66-58.

[67] Chang EI, Bonillas RG, El-ftesi S, Ceradini DJ, Vial IN, Chan DA, Michaels Jt, Gurtner GC. Tissue engineering using autologous microcirculatory beds as vascularized bioscaffolds. Faseb J. 2009; 23(3): 906-915.

[68] Messina A, Bortolotto SK, Cassell OCS, Kelly J, Abberton KM, Morrison WA. Generation of a vascularized organoid using skeletal muscle as the inductive source. The FASEB Journal. 2005; 19(11): $1570-1572$.

[69] Morritt AN, Bortolotto SK, Dilley RJ, et al. Cardiac Tissue Engineering in an In Vivo Vascularized Chamber. Circulation. 2007; 115(3): 353-360.

[70] Forster N, Palmer JA, Yeoh G, Ong WC, Mitchell GM, Slavin J, Tirnitz-Parker J, Morrison WA. Expansion and hepatocytic differentiation of liver progenitor cells in vivo using a vascularized tissue engineering chamber in mice. Tissue engineering Part C, Methods. 2011; 17(3): 359-366.

[71] Hussey AJ, Winardi M, Wilson J, Forster N, Morrison WA, Penington AJ, Knight KR, Feeney SJ. Pancreatic islet transplantation using vascularised chambers containing nerve growth factor ameliorates hyperglycaemia in diabetic mice. Cells, tissues, organs. 2010; 191(5): 382-393.

[72] Stillaert FB, Abberton KM, Keramidaris E, Thompson EW, Blondeel PN, Morrison WA. Intrinsics and dynamics of fat grafts: an in vitro study. Plast Reconstr Surg. 2010; 126(4): 1155-1162.

[73] Schofield R. The relationship between the spleen colony-forming cell and the haemopoietic stem cell. Blood cells. 1978; 4(1-2): 7-25.

[74] Calvi LM, Adams GB, Weibrecht KW, et al. Osteoblastic cells regulate the haematopoietic stem cell niche. Nature. 2003; 425(6960): 841-846.

[75] Kobayashi H, Butler JM, O’Donnell R, et al. Angiocrine factors from Akt-activated endothelial cells balance self-renewal and differentiation of haematopoietic stem cells. Nature cell biology. 2010; 12(11): 1046-1056.

[76] Scadden DT. The stem-cell niche as an entity of action. Nature. 2006; 441(7097): 1075-1079.

[77] Place ES, George JH, Williams CK, Stevens MM. Synthetic polymer scaffolds for tissue engineering. Chem Soc Rev. 2009; 38(1139-1151.

[78] Glowacki J, Mizuno S. Collagen scaffolds for tissue engineering. Biopolymers. 2008; 89(5): 338-344.

[79] Malafaya PB, Silva GA, Reis RL. Natural-origin polymers as carriers and scaffolds for biomolecules and cell delivery in tissue engineering applications. Adv Drug Deliv Rev. 2007; 59(4-5): 207-233.

[80] Griffith LG, Naughton G. Tissue engineering — current challenges and expanding opportunities. SCIENCE. 2002; 295(5557): 1009-1014.

[81] Ryan G, Pandit A, Apatsidis DP. Fabrication methods of porous metals for use in orthopaedic applications. Biomaterials. 2006; 27(13): 2651-2670.

[82] Place ES, Evans ND, Stevens MM. Complexity in biomaterials for tissue engineering. Nat Mater. 2009; 8(6): 457-470. 
[83] Irion S, Clarke RL, Luche H, Kim I, Morrison SJ, Fehling HJ, Keller GM. Temporal specification of blood progenitors from mouse embryonic stem cells and induced pluripotent stem cells. Development. 2010; 137(17): 2829-2839.

[84] Xu C, Inokuma MS, Denham J, Golds K, Kundu P, Gold JD, Carpenter MK. Feeder-free growth of undifferentiated human embryonic stem cells. Nat Biotechnol. 2001; 19(10): 971-974.

[85] Rajala K, Lindroos B, Hussein SM, et al. A defined and xeno-free culture method enabling the establishment of clinical-grade human embryonic, induced pluripotent and adipose stem cells. PLOS ONE. 2010; 5(4): e10246.

[86] Adams GB, Scadden DT. A niche opportunity for stem cell therapeutics. Gene Ther. 2008; 15(2): 9699.

[87] Adams GB, Martin RP, Alley IR, Chabner KT, Cohen KS, Calvi LM, Kronenberg HM, Scadden DT. Therapeutic targeting of a stem cell niche. Nature Biotechnology. 2007; 25(2): 238-243.

[88] Park H, Cannizzaro C, Vunjak-Novakovic G, Langer R, Vacanti CA, Farokhzad OC. Nanofabrication and microfabrication of functional materials for tissue engineering. Tissue Eng. 2007; 13(8): 18671877.

[89] Borenstein JT, Weinberg EJ, Orrick BK, Sundback C, Kaazempur-Mofrad MR, Vacanti JP. Microfabrication of three-dimensional engineered scaffolds. Tissue Eng. 2007; 13(8): 1837-1844.

[90] Qian T, Wang Y. Micro/nano-fabrication technologies for cell biology. Medical and Biological Engineering and Computing. 2010; 48(10): 1023-1032.

[91] Furth ME, Atala A, Van Dyke ME. Smart biomaterials design for tissue engineering and regenerative medicine. Biomaterials. 2007; 28(34): 5068-5073.

[92] Mieszawska AJ, Kaplan DL. Smart biomaterials - regulating cell behavior through signaling molecules. BMC Biol. 2010; 8(59.

[93] Lutolf MP, Hubbell JA. Synthetic biomaterials as instructive extracellular microenvironments for morphogenesis in tissue engineering. Nat Biotechnol. 2005; 23(1): 47-55.

[94] Bianco P, Robey PG. Stem cells in tissue engineering. Nature. 2001; 414(6859): 118-121.

[95] Rahaman MN, Mao JJ. Stem cell-based composite tissue constructs for regenerative medicine. Biotechnol Bioeng. 2005; 91(3): 261-284.

[96] Bajada S, Mazakova I, Richardson JB, Ashammakhi N. Updates on stem cells and their applications in regenerative medicine. J Tissue Eng Regen Med. 2008; 2(4): 169-183.

[97] Vierbuchen T, Ostermeier A, Pang ZP, Kokubu Y, Sudhof TC, Wernig M. Direct conversion of fibroblasts to functional neurons by defined factors. Nature. 2010; 463(7284): 1035-1041.

[98] Ieda M, Fu JD, Delgado-Olguin P, Vedantham V, Hayashi Y, Bruneau BG, Srivastava D. Direct reprogramming of fibroblasts into functional cardiomyocytes by defined factors. Cell. 2010; 142(3): 375386.

[99] Zhou Q, Brown J, Kanarek A, Rajagopal J, Melton DA. In vivo reprogramming of adult pancreatic exocrine cells to beta-cells. Nature. 2008; 455(7213): 627-632.

[100] Levi B, James AW, Nelson ER, Vistnes D, Wu B, Lee M, Gupta A, Longaker MT. Human adipose derived stromal cells heal critical size mouse calvarial defects. PLOS ONE. 2010; 5(6): e11177.

[101] Benoit DS, Schwartz MP, Durney AR, Anseth KS. Small functional groups for controlled differentiation of hydrogel-encapsulated human mesenchymal stem cells. Nature materials. 2008; 7(10): 816823.

[102] Rafii S, Lyden D. Therapeutic stem and progenitor cell transplantation for organ vascularization and regeneration. Nat Med. 2003; 9(6): 702-712.

[103] Sun N, Panetta NJ, Gupta DM, et al. Feeder-free derivation of induced pluripotent stem cells from adult human adipose stem cells. Proc Natl Acad Sci U S A. 2009; 106(37): 15720-15725.

[104] Halvorsen YC, Wilkison WO, Gimble JM. Adipose-derived stromal cells-their utility and potential in bone formation. Int J Obes Relat Metab Disord. 2000; 24 Suppl 4(S41-44.

[105] Mesimaki K, Lindroos B, Tornwall J, Mauno J, Lindqvist C, Kontio R, Miettinen S, Suuronen R. Novel maxillary reconstruction with ectopic bone formation by GMP adipose stem cells. Int J Oral Maxillofac Surg. 2009; 38(3): 201-209. 
[106] Kulakov AA, Goldshtein DV, Grigoryan AS, Rzhaninova AA, Alekseeva IS, Arutyunyan IV, Volkov AV. Clinical study of the efficiency of combined cell transplant on the basis of multipotent mesenchymal stromal adipose tissue cells in patients with pronounced deficit of the maxillary and mandibulary bone tissue. Bull Exp Biol Med. 2008; 146(4): 522-525.

[107] Lendeckel S, Jodicke A, Christophis P, et al. Autologous stem cells (adipose) and fibrin glue used to treat widespread traumatic calvarial defects: case report. J Craniomaxillofac Surg. 2004; 32(6): 370373.

[108] Soto-Gutierrez A, Yagi H, Uygun BE, Navarro-Alvarez N, Uygun K, Kobayashi N, Yang YG, Yarmush ML. Cell delivery: from cell transplantation to organ engineering. Cell Transplant. 19(6): 655-665.

[109] Dhawan A, Mitry RR, Hughes RD, et al. Hepatocyte transplantation for inherited factor VII deficiency. Transplantation. 2004; 78(12): 1812-1814.

[110] Chowdhury JR, Chowdhury NR, Strom SC, Kaufman SS, Horslen S, Fox IJ. Human hepatocyte transplantation: gene therapy and more? Pediatrics. 1998; 102(3 Pt 1): 647-648.

[111] Fox IJ, Chowdhury JR, Kaufman SS, et al. Treatment of the Crigler-Najjar syndrome type I with hepatocyte transplantation. N Engl J Med. 1998; 338(20): 1422-1426.

[112] Grossman M, Rader DJ, Muller DW, et al. A pilot study of ex vivo gene therapy for homozygous familial hypercholesterolaemia. Nat Med. 1995; 1(11): 1148-1154.

[113] Wu YM, Joseph B, Berishvili E, Kumaran V, Gupta S. Hepatocyte transplantation and drug-induced perturbations in liver cell compartments. Hepatology. 2008; 47(1): 279-287.

[114] Janssens S, Dubois C, Bogaert J, et al. Autologous bone marrow-derived stem-cell transfer in patients with ST-segment elevation myocardial infarction: double-blind, randomised controlled trial. Lancet. 2006; 367(9505): 113-121.

[115] Marsboom G, Janssens S. Endothelial progenitor cells: new perspectives and applications in cardiovascular therapies. Expert Rev Cardiovasc Ther. 2008; 6(5): 687-701.

[116] Schachinger V, Erbs S, Elsasser A, et al. Intracoronary bone marrow-derived progenitor cells in acute myocardial infarction. N Engl J Med. 2006; 355(12): 1210-1221.

[117] Wollert KC, Meyer GP, Lotz J, et al. Intracoronary autologous bone-marrow cell transfer after myocardial infarction: the BOOST randomised controlled clinical trial. Lancet. 2004; 364(9429): 141-148.

[118] Rosenzweig A. Cardiac Cell Therapy - Mixed Results from Mixed Cells. New England Journal of Medicine. 2006; 355(12): 1274-1277.

[119] Tokunaga M, Liu ML, Nagai T, et al. Implantation of cardiac progenitor cells using self-assembling peptide improves cardiac function after myocardial infarction. Journal of Molecular and Cellular Cardiology. 2010; 49(6): 972-983.

[120] Xiong Q, Hill KL, Li Q, et al. A Fibrin Patch-Based Enhanced Delivery of Human Embryonic Stem Cell-Derived Vascular Cell Transplantation in a Porcine Model of Postinfarction LV Remodeling. Stem Cells. 2010;

[121] Zhou Q, Zhou JY, Zheng Z, Zhang H, Hu SS. A novel vascularized patch enhances cell survival and modifies ventricular remodeling in a rat myocardial infarction model. The Journal of Thoracic and Cardiovascular Surgery. 2010; 140(6): 1388-1396 e1381-1383.

[122] Chen CH, Wei HJ, Lin WW, et al. Porous tissue grafts sandwiched with multilayered mesenchymal stromal cell sheets induce tissue regeneration for cardiac repair. Cardiovascular Research. 2008; 80(1): 88-95.

[123] Wei HJ, Chen CH, Lee WY, et al. Bioengineered cardiac patch constructed from multilayered mesenchymal stem cells for myocardial repair. Biomaterials. 2008; 29(26): 3547-3556.

[124] Alper J. Geron gets green light for human trial of ES cell-derived product. Nat Biotechnol. 2009; 27(3): 213-214.

[125] Geron I. Geron Initiates Clinical Trial of Human Embryonic Stem Cell-Based Therapy. 2010. http://www.geron.com/investors/factsheet/pressview.aspx?id=1235. Accessed January 12, 2011.

[126] Bretzner F, Gilbert F, Baylis F, Brownstone RM. Target populations for first-in-human embryonic stem cell research in spinal cord injury. Cell Stem Cell. 2011; 8(5): 468-475.

[127] Strauss S. Geron trial resumes, but standards for stem cell trials remain elusive. Nature Biotechnology. 2010; 28(10): 989-990. 


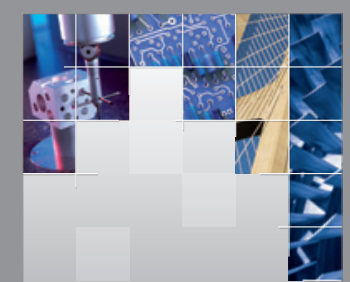

\section{Enfincering}
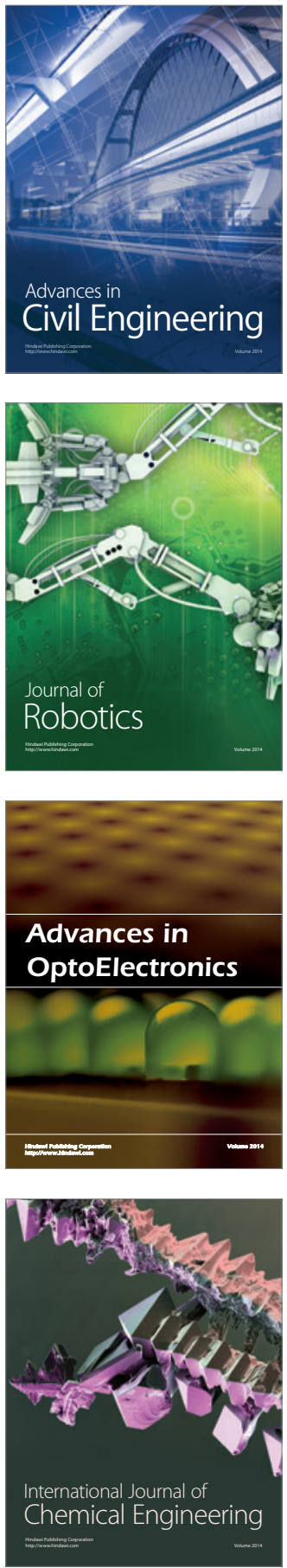

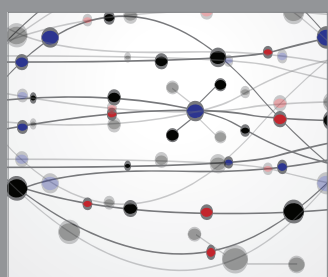

The Scientific World Journal

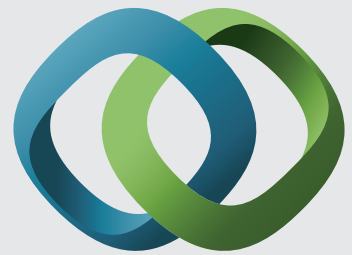

\section{Hindawi}

Submit your manuscripts at

http://www.hindawi.com
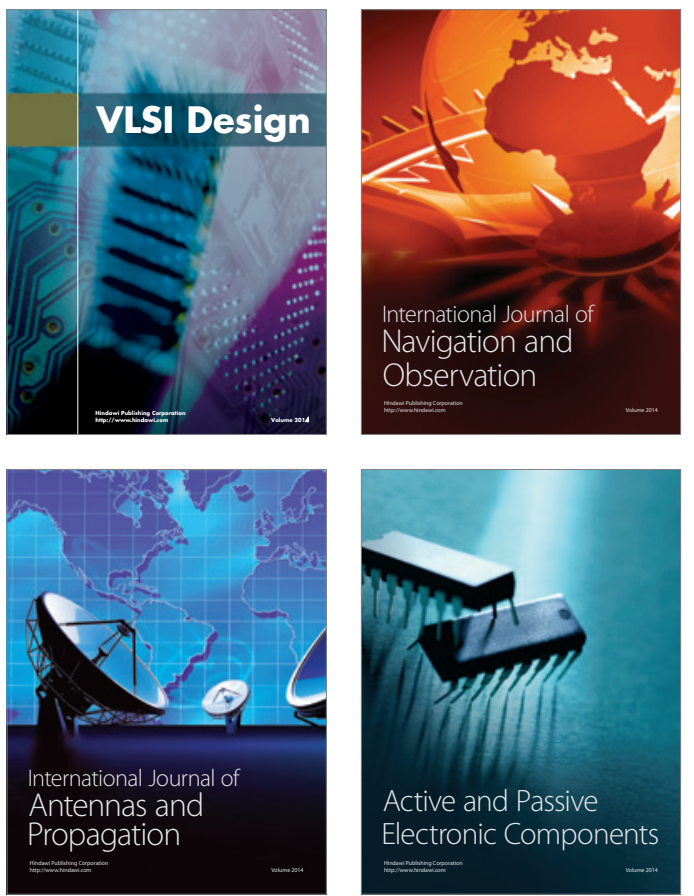
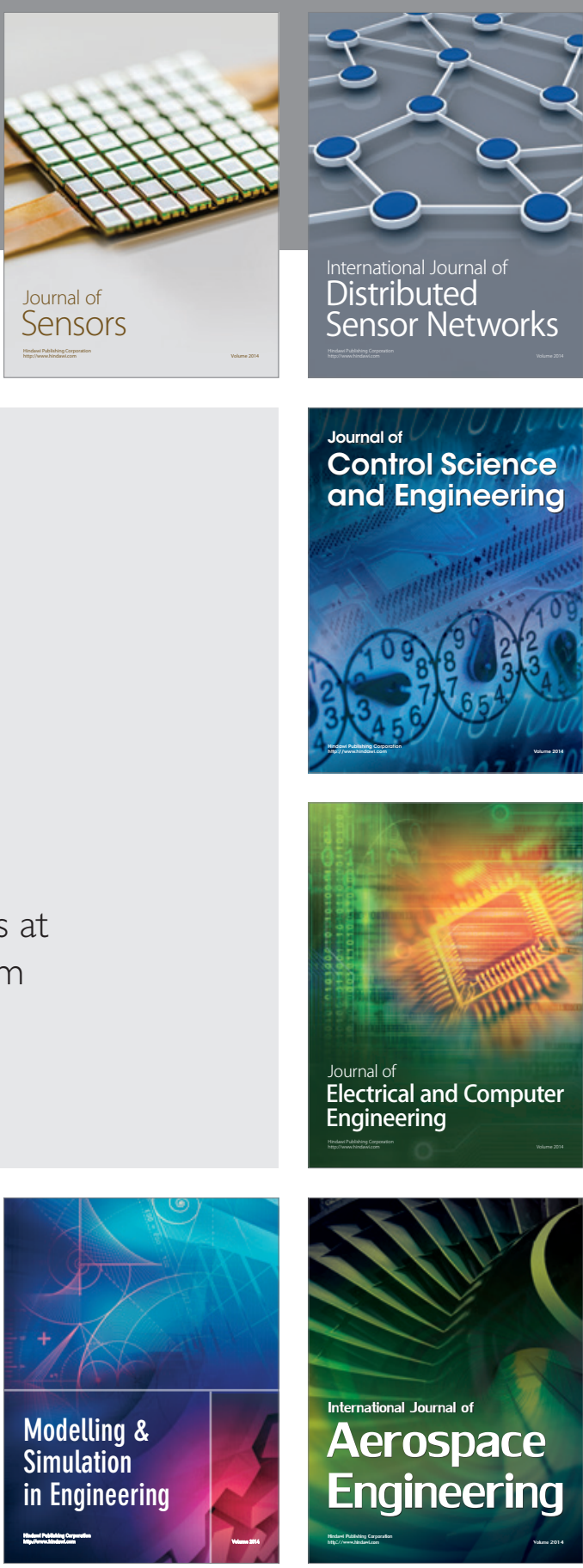

International Journal of

Distributed

Sensor Networks

Journal of

Control Science

and Engineering
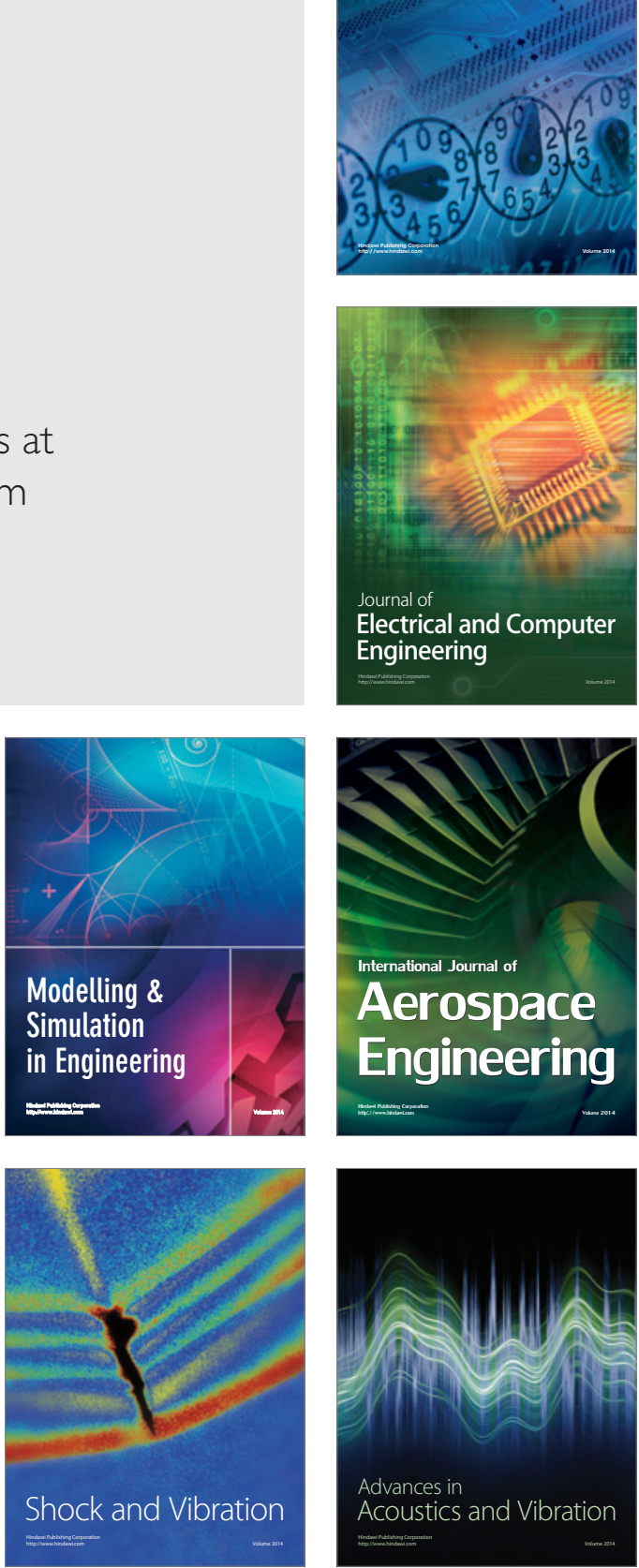